\title{
The Rumor of Globalization: Globalism, Counterworks and the Location of Commodity
}

\author{
BHASKAR MUKHOPADHYAY \\ Department of Sociology, Jadavpur University, Jadavpur, Calcutta, 70032, West Bengal, \\ India (E-mail: b.mukhopadhyay@vsnl.com,privatemiaaow@rediffmail.com)
}

\begin{abstract}
This article seeks to document the vernacular perceptions of 'globalization' in rural Bengal (India) and, in that connection, seeks to rethink some long-held western notions concerning commodity, consumption, representation, the nature of sociality and the politics of democratic empowerment in the third-world. In the subaltern imaginary, images seem to play a crucial role conductive to empowerment. Also, far from resisting globalization and consumption, the rural poor seems to have assimilated these into their vernacular cosmology.
\end{abstract}

Keywords: Globalization, local/global, 'commodity fetishism', consumption, spectacle, simulacrum, gift, democracy, governance, 'Subaltern Studies', community, personhood.

\section{Who is afraid of Cyber-communism?}

\section{Bombard the headquarters!}

A major leitmotif of disquietude about globalization in India has been its supposed inculcation of 'western' consumerism to the gullible Indian masses. This enjoys a broad-based consensus: the RSS thugs (HinduFascist storm-troopers), who routinely smash shops selling totemic 'western' goods like Valentine's Day cards, are not ideologically far removed from the Stalinist crusaders fighting apasanskriti (degenerate culture) in their Left bastion, Calcutta. Denunciation of western 'decadence' and 'hedonism' (bhogbad) is a constant refrain of their cultural propaganda, too. In this regard, the Chinese comrades (to whom the Bengali Stalinists are closely allied), once again, have proved their nettle. Justifying their longstanding censorship of the internet and the crack-down on cyber-cafes, Beijing's Vice-Mayor, Liu Zhihua, came up with a handy aphorism: it is no longer religion but cyber-cafe which is the "opium of the masses". ${ }^{1}$

\footnotetext{
in memoriam: Gourkishore Ghosh (1923-2001) Vernacular intellectual, publicist, crusader for free speech and democracy
} 
Given this rainbow coalition against 'the evil demon of images', I want to celebrate here the imaginaries of consumption in our part of the world haunted by the specter of cyber-communism. I do this by exploring the emergent solidarities engendered by these images, binding ordinary people in their quotidian struggles against the State, the Party, the World Bank, the IMF and other such self-appointed custodians of their destiny. I locate agency in the pleasure experienced by the poor in their enchantment by images of commodities. From Mandeville through Marx to postmodern counter-culture gurus, desire and consumption have consistently been vilified; the experience of consumption is held to be passive and banal, leading to a certain 'bimbofication' of the masses. ${ }^{2}$ I argue that the critique of the so-called passivity of consumption ensues from a messianic desire to purge society by punishing the people for their reversion to idolatry and paganism (more on this later). I show that this didacticism is a throw back from a hoary WESTERN fear of representation as such whose poisoned fruits are, paradoxically, the authoritarian regimes of Asia. I seek to unravel here the diabolical complicity of authoritarianism with the chilling illogic of a utopian 'beyond' of representation.

\section{On 'Interobjectivity'}

Before I come to my untimely meditations on the subaltern imaginaries of consumption, allow me to elaborate on the barest minimum of an analytical framework. My initial entry point is Appadurai's essay on the "semioticity' of things ("methodological fetishism"). ${ }^{3}$ This work is heavy with the recognition that value is not inscribed in the things themselves. This de-ontologisation had the consequence of reclaiming value's intersubjective (or, shall I say, 'interobjective') face. ${ }^{4}$ Before Appadurai, semioticity or cultural thingness was explored by a brand of semiotics practiced by Barthes, Baudrillard etc. As Marxists, they worked hard to peel off the 'ideological' layers of meaning surrounding things, hoping to reach its kernel - a degree zero - where the thing would be equal to itself. Released from the burden of representation, it was hoped, the thing will reappear in its primordial clarity whose locus classicus was laid out by the Cartesian res as modified by the Kantian ontological bipolarity of the transcendental ego and the mute thing-in-itself. This bipolarity is constitutive of what Latour calls the "modern" reality; the 'reality' of the thing as mere ob-ject, emerges out of this framing. ${ }^{5}$ The aim of this essay is to rid progressive politics of this imaginary of the worldless res through which "a beyond of representation is posited 
in such a way that representation could be measured against it."6 'Matter' that matters is always-already inscribed with discourse. The materiality implicated in the Marxist critique of 'commodity fetishism' understood as an "objective illusion", is the materiality of the res. It demands that things be restored to their primal innocence (use-value) by being related directly and transparently to their master, man, without the mediation of market. ${ }^{7}$ This nostalgia for a world of simple objects is grounded in a myth of presence, which informs much of contemporary 'materialist' idealism. ${ }^{8}$ It is my contention that materiality must be understood as materiality effect - the res is a worldless no-thing. Worldly things are cyborgs 9 of sorts - their existential density is wholly due to their inscription with text. It follows that the res is a historical effect, rather than the ground of all history. ${ }^{10}$

Marx treats use-value as a mere foil to bring out the distinctive nature of exchange-value - the artifice per excellence of civil society. He wrote: "Use-value expresses a natural relationship between a thing and a man, the existence of things for man. But exchange value represents the social existence of things": use-value is nature, exchange-value is culture. ${ }^{11}$ Consequently, the work of de-naturalizing use-value and reclaiming its socialness has to begin, of necessity, with Marx who tried to wriggle usevalue out of history. He wrote in Capital I that the history of use-value coincides with the history of discovery of the "properties of things". This 'history' is sham because the notion that the thing is the sum total of its physical properties is itself a product of history.

Marx takes what he calls the "sensuously varied objectivity [of things] as articles of utility" as a timeless fact. ${ }^{12}$ But "facts" are something "constructed... and yet, once constructed... [they have] sufficient existence that none can deny them." ${ }^{13}$ We come upon a scene when things are viewed solely in terms of their 'objective' properties satisfying human 'want' - utility. I propose to treat this 'fact' as a social construction, which has acquired a certain 'durability'. Marx's reservation about market stems from the fact that it homogenizes the 'natural', sensuous singularities of things into the regimented equivalence of exchangevalues. ${ }^{14}$ But Marx's account of exchange-value leaves out something crucial: the emergence, existence and uniqueness of a system of 'goods' subject to a common definition. Political Economy emerged when the existence of this system was already a datum, a 'social fact' and, it took this equivalence for granted. It is well-known how in the eighteenth century there emerged the 'double' discourse of value - aesthetics and political economy - both (beauty and exchange value) being founded in contradistinction to a generalized 'use-value' or 'utility' of objects. ${ }^{15}$ 
Before Political Economy, so to speak, things were organized in a moral hierarchy and not yet normalized into a homogeneous system of 'goods' capable of satisfying human want. The question of equivalence was posed in cases where conflict arose and judges had to decide if an item was of satisfactory quality. The tradition dealing with this taxonomic problem goes back to law and jurisprudence: to judge and to code both come down to classifying a case in a legal category, or, in legal terms, to qualifying it. Law here refers at once to the king - the judge of judges, and to knowledge. So there is a clear link between equity and equivalence: what was once prescriptive, pertaining to morality and law, gradually, through repeated usage, became descriptive. ${ }^{16}$ Thus, 'use-value' - the so-called qualitative character of things as things - as repository of an original and authentic substantiality - is simply the "anthropological alibi" of exchange-value.

Since both use- and exchange-values are historically contingent constructs, it follows that the concept of commodity itself is not 'real'. It is a powerful theoretical fiction yoked with a certain vision about the nature of the present we inhabit. Stated categorically, the script I wish to contest is: through the universalisation of the commodity form, the erstwhile 'unity' of life is torn asunder and images bereft of their referents are made autonomous. Though 'globalization' is the latest phase in the career of the commodity form, so runs the argument, the germ of this development was present essentially in the very imaginary of commodity - in its privileging of representation and mediation over immediacy. Given that, that "capital [would get] accumulated to the point where it becomes image" or "spectacle" - is simply a matter of time. ${ }^{17}$ In its post-Marxist formulation, globalization is the culminating moment of this logic when commodity, freed from its erstwhile territorial underpinning, becomes autonomous and self-referential. ${ }^{18}$ Commodity de-territorialized is the 'spectacle' universalized. "Empire" is the globalization of the "society of spectacle". Negri's 'French exile' has been rather productive: he is still churning the sour milk of ' 68 -style (campus) radicalism!

Using this critique of the commodity form, I want to work out a nonutopian vision of valorizing the present in reporting an incident that took place in Calcutta in the wake of 'globalization'. With the intent of exploring the structural anxiety about commoditization, ${ }^{19}$ I rely not on the angst-ridden visions of post-modern prophets, but on the lived reality of ordinary people. I want to interrogate here their 'take' on commoditization and globalization. Exploring the commodity form through a reading of its meaning(s) as it circulates through the moral economy of the everyday, will alert us to the possibility that commodity, 
"rather than being readable as a constant function", should be thought more as a "relational structure," "possessing different valences in different contexts". ${ }^{20}$

Globalization gone native: the ontology of everyday transactions in a bengali village daan, bakhsish, dakshina and Chinese bicycles

\section{The Production of Globality}

An arresting event took place in Calcutta in May 2001. ${ }^{21}$ Truckloads of villagers from the countryside invaded the city with the objective of buying Chinese consumer goods. Rumor was rife that due to the lifting of restrictions on imports, unbelievably cheap Chinese goods would be sold at the Netaji Indoor Stadium. In early 2001, a systematic disinformation campaign was launched by the Indian big business to create panic about the imminent invasion of Chinese goods. The pro-business print-media carried lead stories on what they dubbed "dumping" of cheap goods by China. ${ }^{22}$ The hysteria ensuing this campaign reached such heights that the then commerce minister had to announce in the Parliament on the 24th of February 2001 that there is no immediate threat of Chinese dumping. What is peculiar about this rumor is that it was transmitted through the electronic media: traders and wholesalers all over the country received faxed messages and emails containing lists of prices. ${ }^{23}$

This rumor had generic similarity to an earlier one: the Hindu God, Ganesh, would drink milk offered by devotees on a certain day in September $1995 .{ }^{24}$ It is believed that this 'miracle' actually happened. This new genre of cyber-rumor is a simulated hybrid: its potency derives not from the relative indeterminacy of word of mouth, but from the cold precision of bytes of data transmitted through silicon chips. Like the Toyota-ridden hybrid Ratha (chariot) of Advani's sinister Rathayatra in $1991^{25}$ or the televised ancient epics of the early ' 90 s, proliferation of these hybrid signifies is a defining feature of India's public culture today. These dissolve, in a manner held to be quintessentially 'postmodern', the sacred into the profane, depth into surface and, and more ominously, for the leftist Kulturkritik, the epochal division of the world in a now and a then. ${ }^{26}$

These cyber rumors are compelling instances of simulacra - a mere 'copy' not backed by an 'original' - the 'truth' or the 'real'. My quarrel with the leftist critiques of Indian public culture erupts at the point when they seek to denude simulation of agency. Rumor is a process of communication through which meanings are produced, transmitted and consumed. Yet, the coding of a message may not, necessarily, control its 
reception: encoding and decoding are separate and autonomous processes. Even with simulated cyber rumors, there remains the agentive moment of decoding. It is from the debilitating shadow of passivity - of consuming passively without having a share in the production of meaning - that I want to rescue the silent majorities and the damning metaphor of simulacra.

More broadly, my title "The Rumor of Globalization" seeks to capture the wider historical unease surrounding globalization - not just a process out there, but also discourses and projects centered around a contested topas, a figurative 'place' in rhetorician's sense of the term. Viewed through the prism of this rumor, in that place, unfolds a war of dreams. Critical studies of globalization phrase it as a totalizing process involving a kind of 'economic' rationality which is devoid of agency the inhuman, 'fantastic' logic of 'things' come to impose itself on what is directly lived - human 'belonging' which is necessarily local, autochthonous, resistant and unmediated by representation. It is my contention that globalization is also an imaginary; it is imagined through metaphors, narratives, and rumors; even its moments of violence are mediated by structures of meaning. These meanings are constitutive of 'globalization' and not simply its flip side or ideological chimeras that mask forms of oppression that are external to them. Finance, interest rates, market, tariff and regulations emerge from a discursive process because the 'economy' itself is a re-presentation, and not the 'real' world itself. If the local is 'constructed', 'produced', so to speak, by what Appadurai calls the work of "social imagination", so is the "global'. Surely, 'globalization' is not One: it is many visions. It is, precisely, a war of contesting visions. To illustrate with our 'rumor of globalization': what was meant to create the semiotic condition of dread, panic and foreboding, as evident from the articles in cold print, turns into a jubilant state of expectancy for arrival of cheap consumer goods which have been denied to the Indian masses.

I want read the figure of globalization against the grain, against one of the most influential strands of contemporary thought concerned with the politics of location - namely, the work of Appadurai. ${ }^{27}$ His contribution has been in de-ontologising the 'local' - in initiating the analysis of how the local is constructed by the global forces in a radically 'delocalized' world. In his reckoning the 'local', far from being the site of a plenitude of meaning, turns out to be a mere effect - caught, as it were, in the interstices of an omnipresent Global. I want to critique the localism of this globalization speak and its metropolitan myopia. 
Appadurai's rightly asserts that locality is the figural effect of cultural-social production. It is performed, produced, rather than being something simply given. Yet, this thinking about locality in the performative is not extended to the 'global'. Granted that the 'local' is produced; but then, by the same logic, one should admit that the 'global' is also 'produced'. At the very least, one cannot take the 'global' as some kind of an ontological ground. Besides, isn't the Global - a certain global - strictly localized in the North? Wanting to bring in a dash of dialogism into what is no more than a tame metropolitan project - 'global civil society' - in a recent essay on 'grassroots globalization', Appadurai makes a case for the funded NGOs as those who, proverbially, think global but act local. ${ }^{28} \mathrm{He}$ identifies these as the agency who would ensure, not just our deliverance from the clutches of the "predatory" nationstate, but also the promotion of a more holistic, 'from below', countervision of globalization - acting as a buffer against the corrosive effects of hyper-mobile finance capital. By evacuating the local political processes altogether as transforming sites, he misses the point that what metropolitan funding begets are oligarchies run by operators with no grassroots accountability. The very real danger inherent in the NGO path is that of depoliticization though their studied indifference to larger questions of class-domination and property ownership. Seeking to supplant rather than supplement the local institutions and being produced through metropolitan fiat rather than broad-based democratic process, their very gesture - cannily but outlandishly condescending - is questionable. To the extent they seek to enforce a certain transnational governmentality - management of things rather than government of men - their locale is circumscribed by the locution called the North. ${ }^{29}$

It is thus perfectly legitimate to think of this 'global' as no more than a localized vision whose production requires work of all sorts, including the ideological work of propagating a certain Eurocentric 'cosmopolitanism'. ${ }^{30}$ One cannot be a constructivist while talking about locality and simultaneously, a realist when thinking globality. The first cosmopolitan among modern philosophers, Kant, clearly stated that cosmopolitanism is necessarily a Weltanschaung - 'world-view', even an ethical project, but never an ontological ground. ${ }^{31}$ This is not to invoke the lurid alterity of a resistant local as some kind of a "primeval community", as a "preexisting ontologicai entity" 32 but simply to point out that we need to strive for a truly global view of globalization as opposed to the parochialism implicated in the project of 'global civil society'. Besides, it is not always autochthony which scripts the local. If we give up the habit of thinking in terms of a "pre-given world of separate and 
discrete "people and cultures" and see instead a difference-producing set of relations, we turn from a project of juxtaposing preexisting differences to one of exploring the construction of differences in the historical process." ${ }^{, 33}$ This is what I set out to do here while studying a case - the production of globality in a specific site: namely, a Bengali village near Sabang in West Midnapore in India. ${ }^{34}$

To get on with the incident of the rumor in Calcutta. Arriving at the Stadium early in the morning, the villagers have queued up like disciplined soldiers. By ten o' clock, the unnerved administration deputed cops in riot gears to disperse the crowd. They declare over loudspeakers that no such 'Sale' is scheduled to take place but in vain. At about 12, the impatient crowd threatened to smash the gates. In order to avoid trouble, the gates were opened. Representative went inside the Stadium and reported back to their folks. Convinced that the venue has been shifted to prevent them from buying the cheap "foren" (foreign) goods in limited supply and that the administration had connived with the rich to corner the goodies for themselves, the disappointed crowd left with bitterness.

Later, by chance, I meet some of these people in a remote village of Midnapore. They came to Calcutta to buy Chinese bicycles, a metonymy for mobility in rural Bengal (a standard Indian bicycle costs Rs. 1200 while a Chinese one with gears was supposed to cost only Rs. 500), What emerged as crucial about their understanding of the Chinese goods is the category of 'gift' in the very special sense they attributed to it. They called these goods "globalizationer daan" (gift of globalization) when I was chiding them for their credulity. Daan in Bengali (derived from Sanskrit dana) means gift.

I do not wish to revisit here the vast ethnographic literature generated in the wake of Mauss's The Gift. ${ }^{35}$ Leaving traditional Melanesia apart, which bears little resemblance to my rural Bengal which has voted a Communist party to power for the last 25 years, I find it difficult to locate an analogue in the 'hard' ethnographic literature on 'gift' to make sense of "globalizationer dann". A distant parallel is found in the early work of Taussig about devil worship. ${ }^{36}$ However, his model of fetishism in which western consumer goods play the role of fetish in the literal sense of the term (animated objects), is inappropriate here since there is nothing 'magical' about our Chinese goods. Why 'gift' then, since one must pay money to acquire these?

I hope a tentative answer emerges from my diminutive ethnography. At the heart of the Marxist theory of the commodity, there is a generalized denunciation of the present as the abstract time of capital as opposed to an 'earlier', 'cyclical' time lived by 'communities'. The series 
of binary oppositions - capital/community, use-/exchange-value, self-interest/altruism - inheres in the commodity/gift opposition. The apparent clarity of the contrast between the two very different forms of social life of things has made it integral to the more general logic that opposes tradition to modernity. But just as that opposition, rather than representing a clear-cut temporal rupture, turns out to be a form of mythical thinking in which the moment of rupture is endlessly repeated, so too, on closer examination, do the concepts of gift and commodity seem to partake of each other: shrewd calculations underlie the mutually obligating gift and, commodities turn out to be constantly endowed with non-commodity, ethical meanings.

After the expression "globalisationer daan" was thrown up in course of conversation, I was waiting in suspended animation for some supplementary statements. To my utter dismay, the villagers went on and on talking about local politics: breathtaking stories of corruption by the cliques formed around the various panchayat bodies dominated by the ruling Communist Party of India (Marxist). These local stories were complemented by more fantastic stories of grafting, bribery and nepotism of the leading leaders of the ruling party quoted from the newspaper Bartaman, which specializes in sensational journalism and was backing Mamata Banerjee, the leader of the opposition party, Trinamul Congress (TMC) - largely a front for the lumpen proletariat - on the eve of the 2002 assembly election. Before the election, the TMC was riding a sudden 'wave' of popularity induced by media-hype though was routed subsequently through electoral debacle.

Since the ethnographer's job is to listen, I sit in a kind of bored trance, growing increasingly restive with their discordant stories. To break out of the stalemate, I decide to argue with the villagers. I tell them that I am not a gullible outsider. I vote the Communists because they are the only force committed to grassroots democracy and empowerment of the poor. Corruption notwithstanding, one must not forget about the wider society which has benefited from leftist rule. Before the left came to power, the question of grassroots corruption could not arise: money started percolating down to the village level only after the panchayat (elected and autonomous village civic bodies) system was introduced. This historic step towards decentralisation was further exacerbated by grass-roots land reforms (Operation Barga). So, their keenness in discussing corruption and local politics is welcome and through such grassroots critique, someday, corruption will give way to a transparent administration. But we must not throw away the baby with the bath-water. 
My little speech failed to produce the desired effect - I found incomprehension writ large on the faces of my audience. The problem seemed to be rooted in the semantic ambiguity of the term "wider society" (brihattaro samaj). What 'society' was I talking about? Was I talking about sikshito samaj (a common expression in subaltern Bengali speech, meaning 'the posh, educated lot')? It is true that the salaried middle class has flourished under left rule, but what about their samaj? My plea that transcending this or that samaj, there is a 'wider-society', fell on deaf ears. The villagers failed to understand what I called an overarching, 'wider society', and we plunged into a dense discussion about samaj, person (lok) and self-other (apan-par, nijer/parer). I meant to tell them that they are parochial; a person must relate directly with society and not just with one's own kin or neighbors. They point out that this is impossible. How can a person be like a solitary, stand-alone "light-post" [lamp-post]? Are they humans or insects ("lok na pok?") How immediate relationships can be so cut and dry ("lepa-poncha") as to be mediated through the abstract protocol of some 'wider society'? I think of relations as something "I" enter into, as after the fact of my personhood, while they think of relations (not in the abstract but very concretely as atmiya-swajan and para-porshi) as constitutive of their personhood. No wonder the villagers think of what I called 'wider society' as a bookish jargon.

It turns out that these villagers' practices of life neither presuppose nor evince, after the fact, anything like 'society' and its corollary, 'individual'. Hence, the search for "the relationship" between the two is misleading. What has been called "clientelism" is precisely a gloss on this phenomenon - the fact that voting and mobilization patterns in Indian politics do not evince the individual as the basic unit of decision-making. ${ }^{37}$ Pundits of Indian politics talk of 'ascriptive, ${ }^{38}$ rather than 'associative' community in explaining the phenomenon of 'bloc voting' where people vote on the basis of caste, community or other so-called 'primordial' loyalties. The recent NGO interventions in devising novel forms of credit customized to serve the very poor also demonstrates this. The spectacular success of 'micro-finance' - where a group as a whole stands as collateral for debts incurred by its members - reveals a pattern of behavior grossly at odds with the received notions of personhood, property and agency. ${ }^{39}$

The Bengali word for sociality, samaj, resists translation. All the authoritative dictionaries of Bengali language assert that samaj is primarily an assembly representing a particular jati of a particular locality. ${ }^{40}$ It also means a particular and localized group of people or a 
face-to-face milieu. The root meaning of samaj is a contingent congregation - a coming together of people for a specific purpose. It is an event, even a performance but never a thing, as in Durkheimian 'society' - a putative anthropological constant.

In recent times, anthropologists have attempted to interrogate the category of 'society': it is no longer thought as a condition humana. Strathern set the agenda when she asked rhetorically: "In what kind of cultural contexts do people's self-description include a representation of themselves as society?" 41 In social theory, influenced by Charles Taylor and Castoriadis, Poovey (among others) has attempted a deconstruction of the 'social': the kind of durability and autonomy it has acquired in the west is shown to be a part of the long process of reification that we call modernity. ${ }^{42}$

The Bengali debate on samaj goes back to the end of the 19th century and is still smoldering. The debate was shaped by concerns arising out of the vicissitudes of colonial modernity. With the deepening of the Western influence, the development of the modern institution of 'society' (understood in the Arendtian sense of a middle-ground between the family/kinship institutions and the state) implicated in the growth of various civic institutions in late-nineteenth century Calcutta, did not go unnoticed by indigenous thinkers like Rabindranath Tagore. Also, this was the period when what we now call, after Foucault, a certain 'governmentalisation' of the colonial state was under way. To the swadeshi thinker, this appeared as an encroachment on the domain of the samaj and a radical departure from the erstwhile ideal of a polity governed largely by self-regulated institutions centered on kinship. In his famous Swadeshi Samaj (Indigenous Society) (1904) Tagore upheld the ideal of a self-subsistent, resistant 'samaj' autonomous from the state (the samaj/state divide being homologous to the larger paradigmatic nationalist inside/outside divide) as the differencia specificia of 'our' polity as opposed to the embeddedness of the state in European polities. ${ }^{43} \mathrm{He}$ also made it clear that person-concept in samaj is relational. But traditional 'Hindu' or Indian society (I use the word now in a purely descriptive sense), by its very constitution, consisting of numerous samajs at different levels, is not something that can act together ever as one body. The very nature of samaj sociality that operates by differentiation, will prevent this. What holds it together is not solidarity or sociability in the western sense but the symbolic efficacy of a very lose ethic called dharma. So, while Tagore was right in stressing relationality of persons and autonomy of the traditional samajs from state, he was wrong in thinking that relationality can be used to forge an 
effective unity - swadeshi samaj - to promote the cause of indigenous unity against the colonial state. Cultural facts, as Geertz noted, are always already interpretations.

To be more precise, if the erstwhile samajs had to combine into a bloc, nothing less the transformation of the very nature of its sociality would be called for. In fact, I suspect, the transformation of the sociality of samaj into that of society was the hidden agenda of Bengali modernity. But I cannot substantiate this here for obvious reasons. ${ }^{44} \mathrm{I}$ can only note in passing that Tagore's project of activating the swadeshi samaj or the nationalist project of constructing a resistant 'inside', was a historic attempt to forge a social body - 'society' - ex nihilo. However tentative and tenuous was this 'society', it was an entity - a 'thing' - that was acted upon in nationalist mobilizations (especially after Gandhi) against the colonial state. To the extent pedagogic nationalism was successful, this imaginary institution of 'society' was not a mere figment of elite imagination: repeated enactments performed it.

Some of Tagore's contemporaries did recognize that the model of swadeshi samaj whose professed aim was to consolidate samajs vis-à-vis the colonial state, goes against the very grain of the sociality of the samajs. Strong objections about Tagore's project came from the 'traditionalist' lobby (in their mouthpiece, Bangabasi, the conservative Bengali journal) - the last bastion of what was still left of the samajs and their garrulous, reactionary samajpatis. ${ }^{45}$ They accused Tagore of subverting the traditional samaj order by his tendentious depiction of swadeshi samaj as somekind of a mélange. If samaj becomes an homogenous collectivity, defining itself as a unified bloc vis-à-vis the state, the principle of samaj, that which holds it together - dharma (read caste and hierarchy) - will be undermined and an European-style 'society' will triumph. We might add here that the traditional discourse of samaj immanent in our regulative smriti texts never posited an environmentlike society and its bond, sociability.

As I have said, I cannot afford to narrate here the history of transformation of Bengali sociality - the transformation of samaj into 'society'. But the very real existence of the 'unequal' languages in contemporary Bengal - the villagers' incomprehension of my 'wider society' - indicates the tenacious underground persistence of samaj and the still tenuous nature of the institution of 'society'. To be fair to Tagore, it should be mentioned that elsewhere, in a different context, he did admit that until recently (we are in 1894), we were a "samaj of householders". Which is to say, there was no middle-ground between the household and the state: there was no 'society'. What I have said so far should make it 
abundantly clear that samaj cannot be posited even as a weak substitute of society. Samaj is not only not society, it is something else altogether. Largely due to the operations of colonialism, "A new flood has swept into its [samaj's] domain. Its name is 'the public' [original in English]... It is impossible to translate it into Bengali... Now our samaj consists not only of households but also an emergent public." 46

To bring out the nature of sociality of samaj, it would be instructive to contrast it with the notion of 'community' preached by the influential "Subaltern Studies" group of historians. 'Community' was salvaged from the dusty alcove of 19th century historical sociology and is simply the binary opposite of 'association'. I find 'community' unhelpful for dethroning the concept of person qua individual idealized in Western political theory. In Partha Chatterjee's acclaimed The Nation and Its Fragments, 'community' is presented as a critique of methodological individualism. Using the origin-myth of a subaltern Bengali sect as a 'cultural critique' of liberalism, Chatterjee idealizes the image of society as an organic body (Gemeinschaft) of which the various jatis are interdependent parts. This organicism of Gemeinschaft is contrasted with the unsocial sociability of civil society. And yet, his very posing of the problem of sociality in terms of a putatively 'universal' problem of "the unity of mutual separateness and mutual dependence" (his words) of persons ${ }^{47}$, suggests as if there is an axiomatic context of action everywhere and, has the effect of making 'society' a universal, removing the very possibility of eliciting other socialities. So long as individuals are imagined as conceptually distinct from the relations that bring them together, we would not be able even to raise the problem of the sociality of samaj.

Chatterjee's 'community' takes its final shape through a reworking of Hegel's section on "Ethical Life" in The Philosophy of Right as a 'suppressed' narrative of the 'community'. He argues for an ethical priority of the organicism of kinship over the principle of bourgeois equality. The underlying argument is familiar: before that historic separation of man from what Marx called "the original conditions of production", society was an organic whole immersed in a time before representation. Enveloped in 'custom' people experienced 'nature' and themselves in an unmediated immediacy ("irreducible immediacy" till market and commodity, the forces of bürgerliche Gesellschaft (civil/ bourgeois society) that is, raised their ugly heads, alienating people from nature and from themselves. This is, famously, the Left-Hegelianism of the Marx of 1844: Schiller's Romantic theory of alienation amplified and then projected on a world-historical scale. ${ }^{49}$ It is also a historic 
regression from Hegel; for, the Feurebachian 'species love' implicated in this mythic humanist narrative derives heavily from the notion of aesthetic interiority developed by the German Romantics and their reactionary politics of nostalgia.

Capitalism means progressive commoditization. But, and this is crucial, the ineluctable logic of commodity also engenders the emphatically de-commodified domain of family, love and friendship as a kind of paradoxical counter-movement. ${ }^{50}$ 'Love' in Hegel's sense does not predate commodity but is contemporaneous with it. Thus, the question of an ethical priority of what Derrida calls philia over impersonal contractual relationships is simply misconceived. ${ }^{51}$ What Chatterjee chooses to valorize belongs to the very same metaphysics of bourgeois personhood deriving from the interconnected notions of primordial self-ownership, the idea of property as a right of exclusion of others and the Romantic notion of 'authorship' - coalescing in the notion of an originary proprietary right in one's own self and its activities. ${ }^{52}$ Precisely what seems to resist most the alienating logic of commodity viz., the idea of a self-determining, unique, moral person who owns his 'own' works - is, paradoxically, a singular creation of bourgeois law. So, to make a political agenda out of the unmediated 'immediacy' of 'community', is what Carl Schmitt called, in a somewhat different context, "Political Romanticism". 53 Consequently, the 'outside' of commodity is not the 'ethical life' enshrined in the primordial, 'organic' community.

\section{Outside-inside the commodity machine}

Personhood (to be a lok) for my villagers is a result of "transactions", the two axes of which are apan (kin) and par (non-kin). The communitarian ideas I imbibed made me think that the bond of community is the connector between persons and society and further, society is a matter of collectivity. This has the distinct disadvantage of prioritizing 'society' as an a priori, as a reality sui generis (as Durkheim would say), which is never accounted for. In the life-world of my villagers, "single actors are not thought ... [as] indivisible, bounded units; .... Instead... persons are... thought... to be "dividuals" or divisible." ${ }^{54}$ Viewed thus, the villagers "exhibit an elaborate transactional culture, characterized by explicit, institutionalized concern for giving and receiving of many kinds in kinship, work, ... worship" and, I hope to show, even in politics. ${ }^{55}$ The upshot of this is that, both persons and things are produced by exchange or transactions (whereas commodity is produced for 
exchange). People's work in such cultures is not to sustain 'social' relationships through 'reciprocation'. What people must do is to place constraints on the webs of relationships. For the villagers, non-kin (par) relationships are based on solidarities which can be very contingent and fluid as well as long-lasting and durable. Here are some examples of non-kin socialities: swajati - members of one's own jati; those who participate in an adda in a tea-shop, who organize together to celebrate a barwari puja, who follow a religious guru like Baba Lokenath, who follow a specific neta, village fractions formed around various interests, customs, events and agendas. All these are little samajs - even the group of daily passengers commuting to Calcutta by train in 'Midnapore Local' who chant auspicious Harinam to elevate the monotony of a long journey, is called a samaj. The singular person is a derivative of multiple identities - a social microcosm. In Bengali, there is a name for this mode of social action activating intricate networks of cross-cutting solidarities in which people are enmeshed: daladali (translated usually as factionalism). It may not be a bad descriptor of subaltern Bengali sociality as such which, whatever it is, is emphatically not a collective sociability. In so far as 'social action' is concerned, collective life is a unity while singular persons are composite.

I have asserted that exchange produces people as persons and things as gifts. This 'gift-economy' must not be conflated with reciprocity or some generalized altruism. I argue that in India an underground gift culture still governs the informal economy involving the disenfranchised poor (Chatterjee's 'political' as opposed to 'civil' society), and that too, in complicity with the market and the state. ${ }^{56}$

The Bengali expression payee dewar rajniti, meaning a perverse, paternalistic politics, has come into usage during the last 25 years or so. This expression captures with great penetration the kind of negotiations that take place between the villagers and the various civic-governmental institutions. Public goods and facilities (roads, wells, public buildings, electricity, tap-water, hospital etc.) are inevitably seen as 'gift'. Such gifts of unnayan (development) are given to chosen peoples and localities (in exclusion of others) through the mediation of the big men (neta, dada) with 'influence' (their word) - power-brokers at various rungs. There is a category of goods for which the official nomenclature in Bengali is khayrati (alms-giving) - e.g., 'relief' after natural calamities, ad-hoc schemes to provide residential houses and pukka privy, 'foodfor-work' schemes etc. These often come directly stamped with the name of the 'donor' (e.g., Indira Abas Yojona, Jawahar Rojgar Yojona, Rajiv such and such Yojona, Prime Minister's Scheme for this or that) and 
these schemes are announced from the ramparts of the Red Fort by the Prime Minister in his Independence Day speech. Access to these, getting a 'ration' or a BPL card (for access to state-subsidized goods and various other concessions), inclusion in various governmental schemes as beneficiaries, admission of patients to state-run hospitals and even formal registration of a complaint in the police station - all these require mediation of biggies who demand loyalty and who have access to elected representatives, to government officers, to police, to press etc. This loyalty is political capital: if you have taken favor, you will have to pay it back - by voting the candidate your big man favors, by joining political rallies, by campaigning for particular candidates etc. The big man will capitalize on the number of men he can mobilize. This is how 'vote banks' work, leading to 'bloc' voting. This intricate mesh of loyalty, favor and patronage extends from the grassroots to the top. And so does the flows of favors, gifts, obligations and counter-gifts.

The unofficial state, the real state that touches the lives of millions in India, is made sense of, and reciprocally, the state has to operate, of necessity, in terms of this 'moral economy' - what Mauss called the "antiquated and dangerous gift economy". ${ }^{57}$ Yet, there can be no 'gift' in the realm of the modern, governmentalised state. If gift of commodities does emerge as a strategy of governance it is because the modern, 'modular', state still does not rule over all the sectors of our lives: there are other authorities. Thus, there is space for other socialities not pre-empted by the 'social'; there are other, dissonant temporalities different from "the time of the states" ${ }^{58}$ And, there are other thingings, imaginaries of cultural thingness not exhausted by the subject-object idiom of property and possession. It is in this allochronic time and allotopic place, the threshold between two different social lives of things - that of gift and commodity - becomes porous and negotiable. When commodities are inscribed with other, vernacular diacritics, as in the villagers' expression globalizationer daan, they become gift. It is not a case of indeterminacy of social trajectory of things but of multiple determinations, of over-determination. Thus, commodity here has another history not annulled by its life qua commodity. It is to this history that we must turn.

To ponder on the villagers' cultural rationalization of commodity qua 'daan'. It is not just a straightforward desire for imported commodities. On closer examination, it turns out, they were not only wanting things but also wanting people to behave in certain ways. They came up with two key indigenous categories: subidha (privilege) and adhikar (literal meaning, right). The latter, like the word 'globalization', has crept into 
their vocabulary from leftist grassroots propaganda. By adhikar, a rather formal word, usually found in sadhu bhasa, they mean something like 'officially sanctioned', 'formal', and not 'right' in the juridical sense of the term. With the experience of just-held election in mind when massive rigging took place in Midnapore, they said that casting vote is an adhikar but, as things stand, this adhikar, like the adhikar of buying a commodity at 'fair' price, is rarely allowed to be exercised. Hence, these are adhikar only in name; for ordinary villagers like them who are outside the transactional network of the ruling party, these are subidha. Illustrative examples were subsidized kerosene, sugar, grain, 'relief' materials distributed through the panchayats and public goods like tube-wells, roads etc, My villagers inevitably end up paying much more than the official subsidized price for things like kerosene and the beneficiaries of the development and welfare programs are invariably those who are part of the coterie formed around the big-men of the panchayat. The same is true for fertilizer, seed, pesticide and even allopathic medicines. To get unadulterated, "original" (original) stuff, as they call it in their pidgin English, one has to pay a little extra, which they call, euphemistically, dakshina (literally, remuneration paid to the priest for performing puja). Even the police station will not accept a complaint for a common theft without some bakhsish (tip). A quality bicycle at an easy price, with no palms to grease, is therefore a daan from 'globalization'. But the ruling party in the state, for their own narrow vested interests, is trying to malign 'globalization' as is evident from their extensive campaigns against the Dunkel proposal, 'globalization' and the GATT in recent past. Thus, my villagers inhabit an everyday permeated by the archaic patterns of obligation - those dangerous, fluid, subtle generosities that bind persons into an order of relations different from the contractual rationality of commodity - and from which they cannot be easily extricated. The coercive cosmopolitanism enshrined in the neo-liberal creed is "founded on a conformist sense of what it means to be a "person" as an abstract unit of cultural exchange". 59 The mutually obligating gift makes the sense of dwelling of my villagers ontologically different from the neo-liberal habitus. In the vernacular imagination, the putative 'benefits' of globalization are conceived as 'daan' i.e., mediated by the ethic of mutually obligating transactions. Can 'globalization' contain its own spectre - this plague of media-mediated imagination fermenting at the hearts of the world's dispossessed? 


\section{Leftist propaganda and the education of desire}

Though 'fetish' in Taussig's sense is grossly inapplicable here, surely the Chinese bicycle is a place-holder, a substitute-object for their deep and repeatedly frustrated desire to participate in the political process as dignified right-bearing citizens, as subjects of a welfare-state entitled to enjoy the benefits of state-subsidized goods as a matter of right, to participate in the global marketplace as consumers free from the restrictions imposed by a paternalist state. These bicycles are better seen not as passive consumables at all but rather as compressed performances - as scripts for political action.

The point is, these desires are not innate, they were produced. These are not, what Chatterjee called, in another context, the "desire for democratization" of the subaltern masses - their timeless longing for 'autonomy'. ${ }^{60}$ Critiquing the elite ideology of caste as a legitimizing narrative for the appropriation of the labor of the low-castes, he claims, by recourse to the contending 'subaltern' narratives that these, staying within the cosmology of caste, "attempt to define a claim of proprietorship over one's body, to negate ... [its] daily submission ... and its labor to the ... dominant dharma and to assert a domain of bodily activity where it can... disregard those demands." ${ }^{61}$ This feat of absent-mindedness with which the Lockean self-ownership is imputed to Bengali subalterns, deserves notice. The idea of self-ownership is not a fixed ontological position to ground ethnographic descriptions but is itself a construct which should be read from the materials and not into them. Such received forms of subjectivity are straightjackets of identity. Chatterjee's ontology of autonomy crucially hinges on the formation of a sovereign, transcendental, agentive, bourgeois subjectivity. Yet, there is no transcendental normative ground on which to glorify 'autonomy' in general. So, if there is a case for "desire" in Chatterjee's expression, it is his pedagogic desire to divest them of agency as desiring persons.

I want to look into desire's artifactuality, its constructedness and its contingency. I want to interrogate how desires are produced. This particular desire for 'democratization' metonymically related to the Chinese bicycles was produced: first, by Leftist rule which made these villagers political subjects but did not confer on them the accoutrements and entitlements of citizenship. And next, by the 'rumor of globalization', by which I mean the dissemination of a technologically mediated imaginary through media in which is included not just the media hype surrounding the imminent invasion of Chinese goods, but also their prolonged exposure to what they call an iconic "foren" (meaning the 
US-American and European) lifestyle through cable television and video (most villages have video-parlors screening all kinds of films: Bengali, Hindi, dubbed Hollywood films like Titanic and Jurassic Park, and clips of B-grade foreign films, usually 'adult' scenes), but also the (negative) leftist vernacular propaganda in the countryside against globalization, warning people that soon cheap mass-consumption goods of everyday use will flood India at the detriment of indigenous industries. Acknowledging the spectrality of consumerist desires, mediated through the images simulated by the technologies of communication, is commonplace today; but it is rarely appreciated that the very same spectre also fuels formation of new solidarities centered on new desires.

The villagers think of 'globalization' as a process operating from some nether region of the world, involving posh, white, educated people who want the underprivileged Indians to enjoy the same access to quality consumer goods as they do. The central government in Delhi has been agreeable to 'globalization' after protracted negotiations - after being threatened of being thrown out of the world community. But the ruling party of this state, for their own narrow vested interests, is trying to malign 'globalization'. The drift of their argument is that enjoying 'right' (adhikar) itself is a 'privilege' (subidha). The Leftist regime inculcated in them the rhetoric of 'right' through their initial mobilization around the issue of recording the names of the poor sharecroppers. That was the first gift of 'right'. Then came the gift of panchayat, resulting in improved village infrastructure and enhanced accessibility to 'gifts' from the state. But then, the same Leftists started deriving special privileges out of the system, now narrowly constricted into a coterie. Thus the desire for democratization I am concerned with resulted from the Leftist pedagogy of 'right' ("Adhikar keu diye day na, adhikar ladai kore chinye nite hoy" - a popular Leftist slogan) as modified by wily popular understanding: this right to right is domesticated as 'gift' from the Leftist regime which presupposes calculation from both the donor and the recipient. The gift of this 'right' must be paid back and matched by the obligation to vote the Left and bring them to power. Exactly the same is true for the 'gift of globalization': it entails the potential recipients to enter into a sticky moral obligation with 'globalization', which means, minimally, denouncing leftist propaganda against globalization as hogwash. Thus, the Chinese bicycle is both a commodity (since it has been produced for exchange, one has to pay a price) and a gift (since it is produced by exchange between the villagers and the globalization process). 


\section{On the banality of the evils of commodity fetishism: enchantment, fetishism, location}

It is clear that some kind of enchantment is implicated in my villagers' desire for imported consumer goods. Taussig would have us believe that the world's dispossessed attaches a negative valence to the spectral: precisely because these are enchanting, these are also dangerous. There is an easy conflation here between Marx's aesthetic-anthropological critique of commodity's fetish character and the noble savage's putative ambivalence towards the spectral. This denunciation of seduction by the spectral rests on a more fundamental distrust of representation as such. Wrote Baudrillard, the melancholic, fatalist prophet of Postmodernism:

"[A]t stake has always been the murderous capacity of images, murderers of the real, murderers of their own model... To this murderous capacity is opposed the dialectical capacity of representations as a visible and intelligible mediation of the Real. All of Western faith ... was engaged in this wager on representation: that a sign could refer to the depth of meaning, that a sign could exchange for meaning, and that something could guarantee this exchange - God, of course. But what if God himself can be simulated, that is to say, reduced to the signs which attest his existence? Then the whole system becomes weightless, it is no longer anything but a gigantic simulacrum - not unreal, but a simulacrum, never again exchanging for what is real, but exchanging in itself, in an uninterrupted circuit without reference or circumference." 62

Debord-dada, as we would say in Bengali, is more direct: "Whenever representation takes on an independent existence, the spectacle establishes its rule." ${ }^{63}$ What underlies the Marxist critique of commodity as 'fetish', a category Marx picked up directly from Enlightenment anthropology of religion, is precisely a denunciation of the simulacra which links Marx, to an unbroken line of tradition which runs from Plato to the Romantics through the Schoolmen and Luther. There is a persistent and morally valorized ontological opposition throughout the Western tradition between likeness and presence, between things fabricated by man and those given by nature or god. We recall in Plato's Sophist a clear-cut distinction between two kinds of images: copies and simulacra. The copies are good images, the icons which resemble from within while simulacra are bad and false images. Copies embody presence, simulacra is mere likeness with no reassuring presence to back it. It is a copy without an original. Deleuze writes: "[W]ith Plato a philo- 
sophical decision of the utmost importance was taken": that the phantasm or simulacra is the devil, the Sophist, that always disguised and displaced false pretender as opposed to god, the demiurge, the only true and authentic 'maker'. ${ }^{64}$

The reason behind my cursory harangue into philosophy is strictly polemical. Recently, William Pietz has attempted to restore to fetish its historically specific meaning(s). ${ }^{65}$ Pietz's philological point about the semantic broadening of 'fetish' in the course of Euro-African first encounter is well taken but the import of this philological 'discovery' is not as radical as he supposes: all sorts of worldly 'illusions' about the 'real' nature of things are already taken care of in Plato's 'simulacra'. Pietz is traversing the same Platonic path in thinking that the "untranscended materiality" of res can be taken as an ontological ground, a transcendental signified, against which is to be measured its various 'objective' (mis)representations like 'commodity fetishism'. The distinction between materiality and its representation is of course a distinction between two signifieds (not between a representation and a referent), involving a characteristically rhetorical production of 'materiality-effect'.

Enlightenment anthropology's derogatory term 'fetish', deriving from the Latin adjective facticius (root-meaning: man-made or artificial), has a long genealogy. It is not the semantic history of a word but the continuity of a certain substratum of meaning that concerns me. It began its career as simulacra in Plato to be used later by Schoolmen ("Thou shalt not make graven images."). Icons flourished under Christianity but not as presence but as likeness. ${ }^{66}$ The icons and idols of the heathens (often referred as 'fetish') - claiming to embody not just likeness but also presence - crumbled as soon as Jesus entered the scene. After Reformation, Protestant philosophers condemned all erstwhile icons and images, including those of the Catholics, as idolatry, as fetish. Koerner has demonstrated brilliantly how the Reformation image incorporated a certain reflexivity such that the icon itself became iconoclastic. ${ }^{67}$ It takes little imagination to see why fetish became a key term for condemning the practices of the heathens in early colonial encounters and finally, institutionalized as an object of study through academic anthropology around 1800. It is at this point that Marx picked it up as a category to demystify the 'idolatry' of commodity in modern societies. Thus, there is a red thread of discursive continuity from Plato to Marx: 'fetish' is tainted. Its cutting edge derives from the Ur-Präsenz of an origin, an $U r$-Modell, and the priority of the model over the copy, whose untruth is measured precisely by its deviation from the original. Use-value, the selfsame and the self-identical, original and authentic substantiality of 
things as things, is the origin of value. Exchange-value is the false pretender, the Sophist. What I am trying to do is to unyoke the theorization of commodity from these metaphysical presumptions.

Commodity has a location, it is not the same thing everywhere: it is ontologically heterogeneous. There is a certain specificity of my villagers' entanglement with 'foren' commodities: far from epitomizing people's powerlessness and lack of control over their own destinies, here the bicycles function as tangible and public celebrations of power of the dispossessed. Following Jane Bennett, the question 1 wish to pose is: "what are the implications for politics when consumables appear as animate, as politically and symbolically valorized?"68

Marx's critique of fetishism hinges crucially on the Cartesian characterization of matter as res whose innate character is inert. This supports an onto-story in which agency is concentrated only in humans. I see the Chinese bicycle as expressive of a different ontology: in it, the liveliness of politicized matter itself is at once apparent, by the grace of the technology of media (hybrid, simulated rumor) and the political technology of producing citizens. These bicycles thus emerge from a subversive, underground cultural sense of porosity between things and persons, from a culture of 'transaction' grounded in a different set of notions of property, possession and person. Out of the commercialized beckoning of Chinese bicycles erupts a cosmology where the self is not an interiority, something one owns, but a node in a network where the paradigmatic altruism/selfishness, human/non-human divides are unobtrusively but incontrovertibly breached.

I have tried to underscore the lack of ready availability of a (meta) narrative called 'commodity' in appropriating the kind of intransigence coded in my Chinese bicycles. This intransigence is also productive in interrogating the theories of location which ontologise the global as ground. Finally, it is this intransigence that calls into question the generalized denunciation of commodity and the spectral. It is the media simulated spectral that activates discordant imaginaries of vernacular globalization, glaringly at odds with the bloodless vision of 'global civil society'.

\section{Acknowledgement}

I am most grateful to Kaushik Ghosh, Suha Chakravorty-Dasgupta, Christopher Pinney, Marilyn Strathern, John Frow, Manas Ray, Natasha Eaton, Markus Deschell, Goutam Bhadra, John Hutnyk and to the audiences at $\mathrm{Ku}-$ ala Lumpur (SEPHIS conference on globalization) Calcutta, Delhi, Edin- 
burgh and London for their comments, interventions and suggestions. As always, and despite some of our persistent disagreements, I am deeply indebted to my teacher, Partha Chatterjee. The responsibility for the remaining errors and infelicities is of course mine.

\section{Notes}

1 The Strait Times 19 June, 2002, Singapore cited in The Statesman 20 June, 2002, Calcutta.

2 'Bimbofication': to turn somebody or a body of people into passive bimbo(s); according to most Marxist commentators, this is what late-capitalism does to people at large. See, Robert D'Amico, "Desire and the Commodity Form," Telos 35 (Spring 1978), pp. 88-122.

3 The 'semioticity' of something means its symbolic or social meaning. Things are not just what they do for us, they are also signs which mean something. For example, a refrigerator cools but to the extent it is a sign (everything is a sign), it also signifies: it signifies the social status of the owner, his/her aesthetic inclination, economic status etc. And of course, there are many things whose semioticity is zero (e.g., chemical salts kept in a laboratory). See, Arjun Appadurai, "Introduction: Commodities and the Politics of Value," in A. Appadurai (ed.), The Social Life of Things: Commodities in Cultural Perspectives, Cambridge: Cambridge University Press, 1986. pp. 3-63.

${ }^{4}$ Michel Serres, Genesis (tr.) G. James and J. Nielson, 1998, Ann Arbor: University of Michigan Press, p. 91. See also, Bruno Latour, "On Interobjectivity" (tr.) G. Bowker, Mind, Culture and Activity, 3:4 (1996), pp. 228-245.

5 Bruno Latour, "One More Turn after the Social Turn: easing science studies into the non-modern world," in E. McMullin (ed.), The Social Dimensions of Science, 1992, Notre Dame: University of Notre Dame Press, p. 277.

6 John Frow, "A Pebble, a Camera, a Man Who Turns into a Telegraph Pole," Critical Inquiry 2\% (2001), p. 271

7 Stephen Gaukroger, "Romanticism and Decommodification: Marx's Conception of Socialism," Economy and Society, 15:3 (1986), pp. 287-333.

${ }^{8}$ William Pietz, "Fetishism and Materialism: The Limits of Theory in Marx," in E Apter and W. Pietz (eds.), Fetishism as Cultural Discourse, 1993, Ithaca: Cornell University Press, pp. 119-151.

${ }^{9}$ Cyborgs are sci-fi characters: half-human, half-machine. Following Donna Haraway, I use this term here to designate a certain constitutive hibridity of worldly things we encounter in our everyday lives. These are not just bare matter, but also discourse. See, Donna J. Haraway, Simians, Cyborgs and Women: The Reinvention of Nature, 1991, New York: Routledge.

${ }^{10}$ Martin Heidegger, What is a Thing?, (trs.) WB Barton, Jr. and Vera Deutsch, 1967, Washington DC: University Press of America.

${ }^{11}$ Karl Marx, Theorien uberden Mehwert, Vol. III, 1910, p. 355 cited in I .I. Rubin, Essays on Marx's Theory of Value, (trs.) M.Samardzija and F. Perlman, Detroit: Black and Red, 1972, p. 28, footnote 7. An interesting reading of Marxist value theory can be found in, Gayatri Chakravorty Spivac, "Scattered Speculations on the Question of Value" in G.C. Spivak, In Other Worlds: Essays in Cultural Politics, 1987, New York: Methuen, pp. 154-175. 
12 The inscription of the thing with the finality of human 'use' is a cornerstone of productivist metaphysics. In holistic societies, things qua sacra are forever in a state of flux, their material boundaries are indeterminate, like the human and super-human beings with whom they are enchained through endless cycles of prestations. (cf. Jean Baudrillard, The Mirror of Production, (tr.) Mark Poster, 1975, St. Louis: Telos Press). Historical evidence as well as ethnography shows that symbolic exchange and not use is the prime-mover in holistic societies. See, for example, Cecil Barraud, Danniel de Coppet, et al., Of Relations and the Dead: Four Societies Viewed from the Point of View of Exchange, (tr.) S. J. Suffern, 1994, Oxford: Berg. And, Natalie Zemon Devis, The Gift in Sixteenth Century France, 2000, Oxford: Oxford University Press.

13 Alain Desrosières, "How to make things which hold together: social science, statistics and the state," in P. Wagner, B, Wittcocq et al (eds.), Discourses on Society, 1990, Dordrecht: Kluwer, p. 195.

${ }^{14}$ For a recent exploration of Marxist use-value, see Peter Stallybrass, "Marx's Coat", in Patricia Spyer (ed.), Border Fetishisms: Material Objects in Unstable Spaces, 1997, New York: Routledge, pp. 183-207.

15 Howard Caygill, The Art of Judgement, 1989, Oxford: Blackwell.

16 Desrosières, op. cit., p. 199. Also, Marcel Gauchet, The Disenchantment of the World: A Political History of Religion, (tr.) Oscar Burge, 1997, Princeton: Princeton University Press, pp. 67-76.

17 Guy Debord, The Society of the Spectacle, (tr.) D. Nicholson-Smith, 1995, New York: Zone Books, p. 33.

${ }_{18}$ Michael Hardt and Antonio Negri, Empire, 2000, Cambridge: Harvard University Press.

19 Keith Hart, "On commoditization," in Esther N. Goody (ed.), From Craft to Industry, 1982, Cambridge: Cambridge University Press, pp. 38-49.

${ }^{20}$ John Frow, Time and Commodity Culture: Essays in Cultural Theory and Postmodernity, 1997, Oxford: Clarendon Press, p. 8.

21 Anandabazar Patrika, "Saster China Jinis Bikrir Gujab, Hujuge Bhir Indoor", Calcutta, 26 May, 2001. Anandabazar Patrika, "Saster Gujabe Thaw China Panya Bikeretarao", Calcutta, 27 May 2001. The Telegraph, "Big Draw: The China fair that never was", Calcutta, 26 May 2001.

22 India Today "Taste of China" [Cover story], New Delhi: December 11(2000).

23 Anandabazar, 27 May, 2000, op. cit.

24 Denis Vidal, "When the Gods Drank Milk: Empiricism and Belief in Contemporary Hinduism," South Asia Research, 18:2, (1998), pp. 149-171.

25 L.K. Advani's (Deputy Prime Minister of the erstwhile BJP government) Rathayatra prepared the ground for the demolition of the Babri mosque in December 1991 which sparked off communal riots all over the country. It is remembered as a watershed when Indian politics, after about half a century of state-backed 'secularism', entered a 'communal' phase.

26 Arvind Rajagopal, Politics after Television: Nationalism and the Reshaping of the Public in India, 2001, Cambridge: Cambridge University Press, pp. 72-150.

27 Arjun Appadurai, "The Production of Locality" in Modernity at Large, 1995, Delhi: Oxford University Press, pp. 178-200.

28 Arjun Appadurai, "Grassroots Globalization and the Research Imagination", Public Culture, 12:1 (2000), pp. 1-19. 
29 Akhil Gupta and James Ferguson "Sptializing States: Toward an ethnography of neoliberal governmentality, American Ethnologist, 29:4 (2002), pp. 981-1002.

${ }^{30}$ Nussbaum makes the case for inculcating the responsibilities of global citizenship through distinctive educational programs. There is, thus, a distinctive pedagogy of the global: it is an ethical project See: Martha Nussbaum and her respondents, For Love of County: Debating the limits of patriotism, 1996, Boston: Beacon Press. Also, Martha Nussbaum, "Kant and Stoic Cosmopolitanism," Journal of Political Philosophy, 5 (1997), pp. 1-25. For a trenchant critique of globality as ground, see Gayatri Chakravorty Spivac, "Cultural Talks in the Hot Peace: Revisiting the "Global Village," in Pheng Cheah and Bruce Robbins (eds.), Cosmopolitics: Thinking and Feeling Beyond the Nation, Minneapolis: University of Minnesota Press, 1998, pp. 329-348.

${ }^{31}$ Immanuel Kant, Critique of Judgment, (tr.) W.S. Pluhar, 1987, Indianapolis: Indiana University Press, p. 111.

32 Akhil Gupta and James Ferguson, "Beyond "Culture": Space, Identity and the Politics of Diffference," in J. X. Inda and R Rosaldo (eds.), The Anthropology of Globalization, 2002, Oxford: Blackwell, p. 73.

${ }^{33}$ Ibid., p. 74, emphasis mine.

${ }^{34}$ Sabang is near Keshpur in West Midnapore where massive political violence took place on the eve of the assembly elections, killing at least a dozen people who belonged to the opposition party. Its cadres are still terrorized and cannot enter their own villages. My respondents were mostly sympathizers of the opposition party and before talking to me they made me promise that I would not disclose their names or the name of their village.

${ }^{35}$ Marcel Mauss, The Gift: Forms and Functions of Exchange in Archaic Societies, (tr.) lan Cunnison, 1967, New York: Norton.

${ }^{36}$ Michael Taussig, The Devil and Commodity Fetishism in South America, 1983, Chapel Hill: University of North Carolina Press.

37 Paul Brass, "National Power and Local Politics in India: A Twenty-year Perspective", Modem Asian Studies, 18:1 (1984), pp. 89-118.

38 As opposed to 'associative', 'ascriptive' community means a community constituted around some so-called 'primordial loyalty' like caste, kinship, religion etc.

39 Maitreesh Ghatak and T. W. Guinanne, "The Economics of Lending with Joint Liability: Theory and Practice,". Journal of Development Economics, 60 (1999), pp. 195-228.

${ }^{40}$ Haricharan Bandyopadhyay, Bangiya Sabdokosa, 1967 (BS. 1340), Sahitya Akademy, New Delhi, pp. 2137. Ganendramohan Das, Bangala BhasarAbhidhan, Vol. II, 1979 (BS 1344), Calcutta: Sahitya Samsad, p. 2090. Nagendranath Vasu, Viswakosa, Vol. XXI, 1988 (1886-1911), Delhi: BR Publishing, p. 239.

${ }^{41}$ Marilyn Strathern, The Gender of the gift: Problems with Women and Problems with Society in Melanesia, 1988, Berkley: University of California Press, p. 9.

${ }^{42}$ Mary Poovey, "The liberal civil subject and the social in eighteenth-century British moral philosophy," in Patrick Joyce (ed.), The Social in Question, 2000, London: Routledge, pp. 44-61. Eric R. Wolf, "Inventing Society," American Ethnologist, 15:4 (November 1988), pp. 752-761. Alain Touraine, "Sociology without Society", Current Sociology, 46:2 (April 1998), pp. 119-143.

43 Rabindranath Tagore, "Swadeshi Samaj" (BS 1311), Rabindra Rachanabali, Vol. XII, 1961, Calcutta: Govt. of W.B (centenary edition), pp. 683-702.

${ }^{44}$ In this connection, see my "The Nation and its Memories: Constructing a Bengali Past 1875-1950," paper presented at the conference on Imagined Pasts in South Asia 
at Maison des Sciences de I'Homme, Paris, December 2003 (forthcoming). My idea of samaj has been shaped by Nagendranath Vasu's Banger Jatiya Itihas, XI Vols., 1899-1913, Calcutta: Viswakosh Karyaloy.

45 Rabindranath Tagore, "'Swadeshi Samaj' Prabandher Parishista" (BS 1311), op. cit., p. 706.

46 Rabindranath Tagore, "Shoksabha" (BS 1301), Rabindra Rachanabali, Vol. X, 1989, Calcutta: Govt. of W.B., p. 293.

47 Chatterjee, Partha, The Nation and its Fragments, 1994, Delhi: Oxford University Press, p. 197.

48 Chatterjee, Ibid., p. 232.

49 Friedrich von Schiller, Naïve and Sentimental Poetry (1796), (tr.) J. A. Bias, 1966, New York: F. Ungar.

50 Thomas L. Haskell, "Capitalism and the Origins of the Humanitarian Sensibility," I and II, American Historical Review, 90 (1985), pp. 339-361 and pp. 547-566.

51 Jacques Derrida, Politics of Friendship, (tr.) G. Collins, 1997, London: Verso.

52 John Pocock has reminded us that "property was a juridical term before it was an economic one, it meant that which was properly one's own, that on which one properly had a claim..." (emphasis mine) See JGA Pocock, "Authority and Property: The Question of Liberal Origins" in JGA Pocock, Virtue, Commerce and History, Cambridge: Cambridge University Press, 1985, p. 56.

53 Carl Schmitt, Political Romanticism (1919), (tr.) Guy Oakes, 1986, Cambridge: MIT Press.

${ }^{54}$ McKim Marriott, "Hindu Transactions: Diversity Without Dualism", in B. Kapferer (ed.), Transactions and Meaning, 1976, Philadelphia: ISHI Publications, p. 111.

55 Ibid., p. 109.

56 Partha Chatterjee, "Democracy and the violence of the state: a political negotiation of death", Inter-Asia Cultural Studies, 2:1 (2001), p. 17.

57 Mauss, op. cit., p. 52.

58 Charles Tilly, "The Time of States", Social Research, 63:2 (1994), pp. 267-295.

59 Sheldon Pollock, Homi K Bhabha et al., "Cosmopolitanisms," Public Culture, 12:3 (2000), p. 581.

${ }^{60}$ Chatterjee, Nation, op. cit, p. 197.

61 Ibid., p. 195, emphasis mine.

62 Jean Baudrillard, Simulations, (tr.) Paul Foss, Paul Pattern et al., 1983, New York: Semiotext[e], p. 10.

63 Debord, op. cit., p. 17.

${ }^{64}$ Gilles Deleuze, Difference and Repetition, (tr.) Paul Patton, 1994, London: Athlone, p. 127.

${ }^{65}$ William Pietz, "The Problem of the Fetish, I," Res, 9 (1985), pp. 5-17. William Pietz, "The Problem of the Fetish, II", Res, 13 (1987), pp. 23-45. William Pietz, "The Problem of the Fetish, IIIa", Res, 16 (1988), pp. 105-123.

${ }^{66}$ Hans Belting, Likeness and Presence: A History of Image before the Era of Art, 1994, Chicago: Chicago University Press.

${ }^{67}$ Joseph Leo Koerner, The Reformation of the Image, 2003, Chicago: Chicago University Press.

68 Jane Bennett, The Enchantment of Modem Life: Attachments, Crossings, and Ethics, 2001, Princeton: Princeton University Press, p. 118. 